\title{
Sophocarpine against enterovirus 71 in vitro
}

\author{
ZENGJUN JIN ${ }^{1-3^{*}}$, LIXIN YANG ${ }^{4 *}$, GUOTAO DING ${ }^{3,5}$, GUOXING YANG $^{3}$, \\ YONGHONG HAN ${ }^{3}$, XIA ZHANG ${ }^{6}$ and WEIHAO LI $^{3}$ \\ ${ }^{1}$ State Key Laboratory of Microbial Resources, Institute of Microbiology, \\ Chinese Academy of Sciences, Beijing 100101; ${ }^{2}$ University of The Chinese Academy of Sciences, \\ Beijing 100049; ${ }^{3}$ Handan Municipal Centre for Disease Control and Prevention, Handan, Hebei 056008; \\ ${ }^{4}$ Hebei Centre for Disease Control and Prevention, Shijiazhuang, Hebei 050021; ${ }^{5}$ College of Life Sciences, \\ Hebei Agricultural University, Baoding, Hebei 071001; ${ }^{6}$ School of Life Science and Technology, \\ Tongji University, Shanghai 200092, P.R. China
}

Received February 22, 2017; Accepted July 12, 2017

DOI: $10.3892 / \mathrm{etm} .2017 .4958$

\begin{abstract}
Sophocarpine (SCA) is a bioactive alkaloid present in Sophoraflavescens Ait. The present study demonstrated that SCA inhibited enterovirus 71 (EV71) infection in Vero cells. The results indicated that the $50 \%$ cytotoxicity concentration of SCA for Vero cells was $1,346 \mu \mathrm{g} / \mathrm{ml}$, and the $50 \%$ inhibition concentration of SCA against EV71 was $350 \mu \mathrm{g} / \mathrm{ml}$. SCA produced a marked inhibitory effect against EV71 when the Vero cells were treated with SCA prior to infection with the virus. Additionally, SCA was effective against EV71 when the Vero cells were infected with EV71 $\left(100 \mathrm{xTCID}_{50}\right)$ that had been treated with SCA for $2 \mathrm{~h}$, and was effective when the Vero cells were infected with EV71 $\left(100 x \mathrm{xCID}_{50}\right)$ at $37^{\circ} \mathrm{C}$ under $5 \% \mathrm{CO}_{2}$ for $2 \mathrm{~h}$ prior to treatment with SCA for $2 \mathrm{~h}$. SCA was demonstrated to inhibit the attachment and penetration of EV71 and was more effective at inhibiting attachment. The assay additionally verified that SCA suppressed the replication of viral genomic RNA and indicated that SCA may inhibit EV71 infection in vitro.
\end{abstract}

\section{Introduction}

Enterovirus 71 (EV71) is a single-stranded, positive-polarity RNA virus and belongs to the enterovirus genus, Picornaviridae family (1). EV71 was initially isolated from the brain of a patient in California in 1969 (2), and it was found to trigger cytopathic effect and cellular apoptosis after

Correspondence to: Dr Weihao Li, Handan Municipal Centre for Disease Control and Prevention, 581 Beicang Road, Handan, Hebei 056008, P.R. China

E-mail: jinteng118@hotmail.com

*Contributed equally

Key words: enterovirus 71, sophocarpine, cytopathic effect, antiviral activity infecting microvascular endothelial cells, Jurkat $\mathrm{T}$ cells and neuronal cells (3-5). EV71 was one of the major causes of a hand-foot-and-mouth disease (HFMD) epidemic associated with neurological sequelae (6-9). Previously, Du et al reported that EV71 induced SH-SY5Y human neuroblastoma cells apoptosis by stimulation of endogenous microRNA let-7b expression (10). As pointed out by Cao and Yue et al protective effects of EV71 virus-like particle vaccine against lethal EV71 infection, and genomic and immunologic factors associated with viral pathogenesis in a neonatal mouse model $(11,12)$. In the present study, our data demonstrate that treatment with Sophocarpine (SCA) reduced the viral cytopathic effect on Vero cells. Although vaccines have entered the clinical trial stage (13), drugs are not currently available for the clinical treatment of EV71 infection. Thus, the study of a plant-derived compound against EV71 has important potential.

SCA, an effective compound plant-derived from foxtail-like sophora herb, root and seed, is one of the most abundant alkaloids in Sophora flavescens, and its structure is shown in Fig. 1 insert. Sophora flavescens has been used as a traditional Chinese medicine for more than 2,000 years for the treatment of fever, throat inflammation, and other diseases. SCA is a white colored crystalline alkaloid monomer with the molecular formula $\mathrm{C}_{15} \mathrm{H}_{22} \mathrm{~N}_{2} \mathrm{O}$ and a molecular weight of 246.35. In recent years, studies on SCA have shown an increasing variety of effects, such as anti-arrhythmic, anti-inflammatory, and anticancer effects $(14,15)$. In the present study, we first demonstrate that SCA has the ability to inhibit EV71 induced in Vero cells. Then, we compare the effect of SCA inhibition against EV71 induced in Vero cells when SCA is applied before and after the viral infection is induced. Finally, the experimental result demonstrates that SCA can inhibit viral attachment and RNA replication.

\section{Materials and methods}

Chemicals. Vero cells were obtained from the Institute of Biochemistry and Cell Biology, Shanghai Institute for Biological Sciences, Chinese Academy of Sciences. EV71 was obtained from the Centers for Disease Control and 
Table I. PCR primers used for EV71 and 18S.

\begin{tabular}{llll}
\hline Symbol & \multicolumn{1}{c}{ Forward primer } & \multicolumn{1}{c}{ Reverse primer } & Tm \\
\hline EV71 & ATTTCAGCAGCTTGGAGTGC & GCAGCCCAAAAGAACTTCAC & $45^{\circ} \mathrm{C}$ \\
$18 \mathrm{~S}$ & CGAAACTTTCGTTATTCTTCGC & GTATTCGTCGTTAGGCGTTT & $58^{\circ} \mathrm{C}$ \\
\hline
\end{tabular}

Prevention (CDC; Handan, China). Dulbecco's modified Eagle's medium (DMEM), fetal bovine serum (FBS), trypsin, penicillin, and streptomycin were purchased from Gibco (Carlsbad, CA, USA). 3-[4,5-dimethyltiazol-2-yl]-2.5-diphenyl-tetrazolium bromide (MTT) and dimethyl sulfoxide (DMSO) were purchased from Sigma (St. Louis, MO, USA). SCA was purchased from Baozetang (Suzhou, China). TRIzol Reagent and a reverse transcription kit were purchased from Takara Bio Inc. (Otsu, Japan). Taq DNA Polymerase was purchased from Fermentas (Glen Burnie, MD, USA). An in situ cell death detection kit was purchased from Biyuntian Biotech Co., Ltd., (Shanghai, China).

Viruses and cell cultures. EV71 was propagated in Vero cells using DMEM supplemented with 2\% FBS. The Vero cells were grown in DMEM supplemented with $10 \%$ FBS, penicillin $(100 \mathrm{U} / \mathrm{ml})$, and streptomycin $(100 \mathrm{U} / \mathrm{ml})$. The cells were maintained at $37^{\circ} \mathrm{C}$ in an incubator under an atmosphere of $5 \% \mathrm{CO}_{2}$.

Virus titers obtained by TCID $_{50}$. The Vero cells $\left(5 \mathrm{obt}^{3}\right.$ cells $\left./ \mathrm{ml}\right)$ were seeded into a 96 -well culture plate (100 $\mu \mathrm{l} /$ well) and incubated for $10 \mathrm{~h}$ at $37^{\circ} \mathrm{C}$. Then, the cells were infected with 10 -fold serial dilution viral suspensions, which resulted in 8 concentrations. For each concentration, 12 wells were infected with a $50 \mu \mathrm{l}$ viral suspension and then incubated at $37^{\circ} \mathrm{C}$ under $5 \% \mathrm{CO}_{2}$ for $168 \mathrm{~h}$. The virus titer [reported as $50 \%$ tissue culture infectious doses $\left(\mathrm{TCID}_{50} / \mathrm{ml}\right)$ ] was calculated using the Behrens-Karber method (16).

$C C_{50}(50 \%$ cytotoxicity concentration) assay. Vero cells $\left(1\right.$ ity $^{5}$ cells $\left./ \mathrm{ml}\right)$ were seeded into a 96 -well culture plate (100 $\mu \mathrm{l} /$ well) and incubated for $24 \mathrm{~h}$ at $37^{\circ} \mathrm{C}$. The cells were then treated with SCA at concentrations of 4,000, 2,000, $1,000,500,250,125,62.5,31.25$, and $15.625 \mu \mathrm{g} / \mathrm{ml}$ and incubated at $37^{\circ} \mathrm{C}$ under $5 \% \mathrm{CO}_{2}$ for $48 \mathrm{~h}$. In the negative control, the cells were not treated with SCA, and for the blank test, DMEM was used. The Vero cells in the control and blank test were incubated with $0.5 \mathrm{mg} / \mathrm{ml} \mathrm{MTT}$ at $37^{\circ} \mathrm{C}$ for $4 \mathrm{~h}$, DMSO was then added ( $150 \mu \mathrm{l} /$ well $)$ to dissolve the crystal violet, and the absorbance at $490 \mathrm{~nm}$ was measured using an ELISA plate reader. The same procedure was repeated three times, and the concentration of SCA that killed $50 \%$ of the cells was the $50 \%$ cytotoxicity concentration.

$I C_{50}$ determination by neutralization assay. The Vero cells (1 y ${ }^{5}$ cells $\left./ \mathrm{ml}\right)$ were seeded into a 96 -well culture plate (100 $\mu \mathrm{l} /$ well) and incubated for $24 \mathrm{~h}$ at $37^{\circ} \mathrm{C}$. The cells were exposed to a virus suspension containing $\left(100 \times \mathrm{xCID}_{50}\right)$ and SCA at concentrations of $1,000,500,250,125,62.5$, and

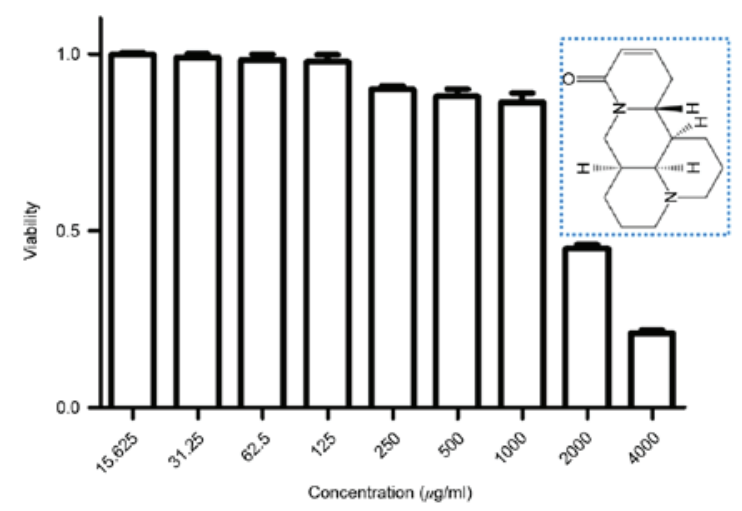

Figure 1. After 2 days of incubation, the cytotoxicity of SCA was determined via an MTT assay. The insert in the blue box is sophocarpine structure. SCA was serially diluted to different concentrations $(15.625,31.25,62.5,125,250$, $500,1,000,2,000$, and $4,000 \mu \mathrm{g} / \mathrm{ml})$ in triplicate.

$31.25 \mu \mathrm{g} / \mathrm{ml}$. The cells were then incubated at $37^{\circ} \mathrm{C}$ under $5 \% \mathrm{CO}_{2}$ for $48 \mathrm{~h}$, and then an MTT assay was performed. The concentrations of SCA that reduced the virus-induced $\mathrm{CPE}$ by $50 \%$ were expressed as the $\mathrm{IC}_{50}(17)$.

Antiviral assays. The Vero cells (1'_ $\mathrm{E}^{5}$ cells/ml) were seeded into a 96-well culture plate (100 $\mu \mathrm{l} /$ well) and incubated for $24 \mathrm{~h}$ at $37^{\circ} \mathrm{C}$. To study the antiviral activity of SCA, the Vero cells were divided into 3 groups. In the first experiment, the Vero cells were infected with EV71 (100xTCID $\left.{ }_{50}\right)$ at $37^{\circ} \mathrm{C}$ under $5 \% \mathrm{CO}_{2}$ for $2 \mathrm{~h}$ and then supplemented with various concentrations of SCA for $2 \mathrm{~h}$. In the second experiment, the Vero cells were infected with EV71 $\left(100 \times\right.$ TCID $\left._{50}\right)$ that had been treated with SCA for $2 \mathrm{~h}$. In the third experiment, the Vero cells were exposed to various concentrations of SCA for $2 \mathrm{~h}$ and then infected with EV71 (100xTCID ${ }_{50}$ ) for $2 \mathrm{~h}$. The same procedure was repeated three times. The cytopathic effect was determined by measuring the cell viability via the MTT assay after $48 \mathrm{~h}$.

Effects of SCA on EV71 attachment. For the attachment assay, the Vero cells $\left(1 \mathrm{nt}{ }^{5} \mathrm{cells} / \mathrm{ml}\right)$ were seeded into a 96 -well culture plate $(100 \mu \mathrm{l} /$ well $)$ and incubated for $24 \mathrm{~h}$ at $37^{\circ} \mathrm{C}$. The cells were pre-chilled at $4^{\circ} \mathrm{C}$ for $1 \mathrm{~h}$, infected with EV71 $\left(100\right.$ illed $_{50}$ ) for $2 \mathrm{~h}$ at $4^{\circ} \mathrm{C}$ to allow for absorption, and then supplemented with SCA at concentrations of 1,000, 500, 250, $125,62.5$, and $31.25 \mu \mathrm{g} / \mathrm{ml}$. The same procedure was repeated three times. The cytopathic effect was determined by measuring the cell viability via the MTT assay after $48 \mathrm{~h}$ (18).

Effects of SCA on EV71 penetration. The Vero cells $\left(1 \mathrm{rat}^{5}\right.$ cells $\left./ \mathrm{ml}\right)$ were seeded into a 96 -well culture plate (100 $\mu \mathrm{l} /$ well) and incubated for $24 \mathrm{~h}$ at $37^{\circ} \mathrm{C}$. The Vero cells were pre-chilled at $4^{\circ} \mathrm{C}$ for $1 \mathrm{~h}$ and then infected with 

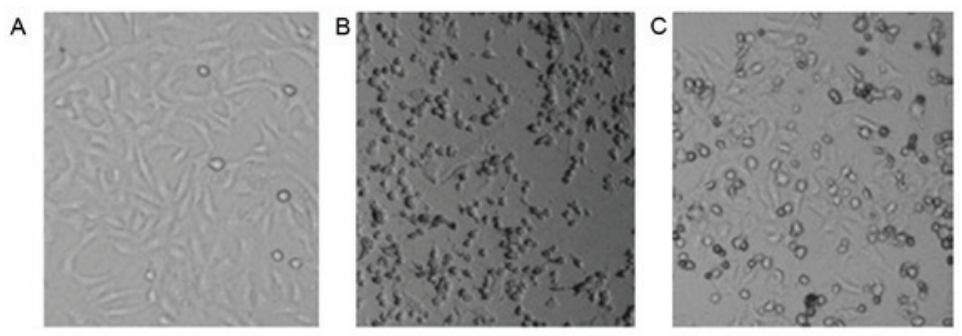

D

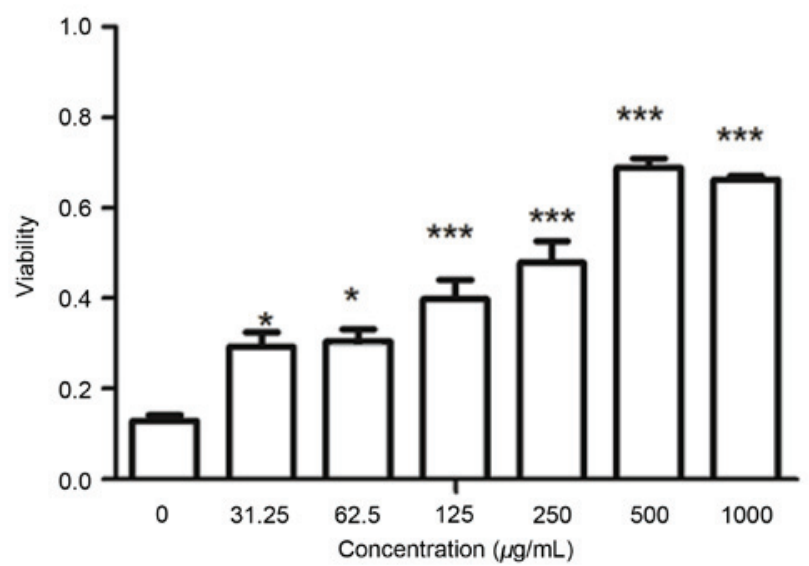

Figure 2. After 2 days of incubation, the cytotoxicity of SCA was determined via an MTT assay. (A-C) Effective concentrations of SCA against EV71 were observed under an inverted microscope. (A) Vero cells. (B) EV71-infected Vero cells. (C) Vero cells exposed to $500 \mu \mathrm{g} / \mathrm{ml}$ SCA (magnification, $\mathrm{x} 40$ ). (D) The Vero cells were exposed to the virus $\left(100 x \mathrm{xCID}_{50}\right)$ and SCA. SCA was serially diluted to different concentrations $(31.25,62.5,125,500 \mathrm{and} 1,000 \mu \mathrm{g} / \mathrm{ml}) \mathrm{in}$ triplicate. ${ }^{*} \mathrm{P}<0.05$ and ${ }^{* * *} \mathrm{P}<0.001$ vs. control. SCA, sophocarpine; EV71, enterovirus 71.
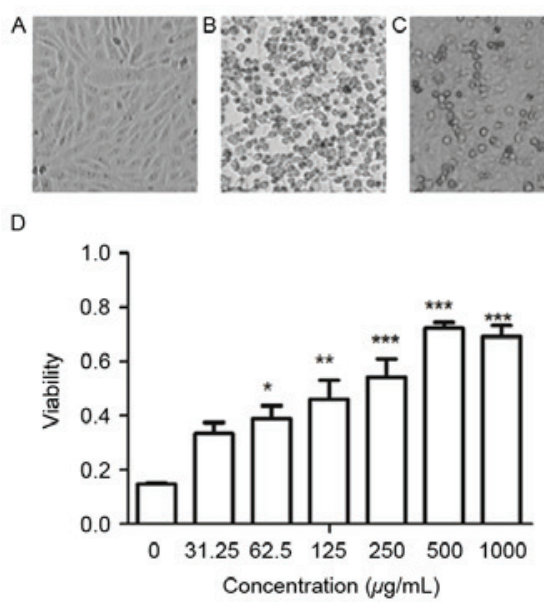

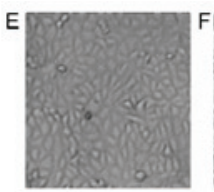

$\mathrm{H}$

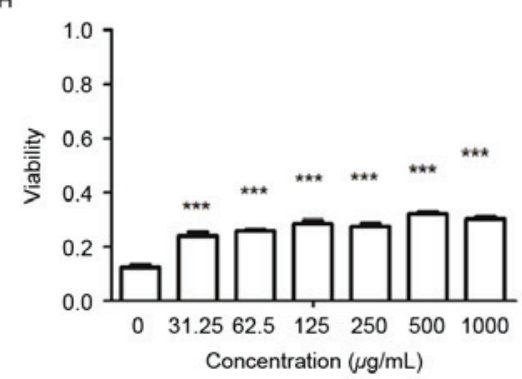

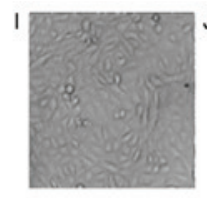
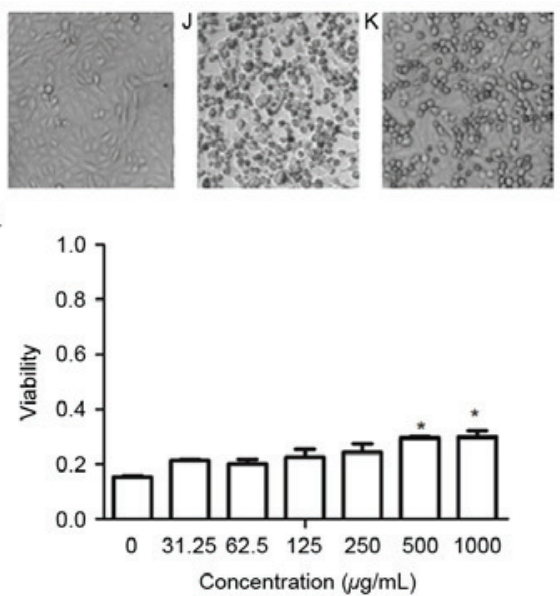

Figure 3. The antiviral activity of SCA using three different treatments. (A-C) Effective concentrations of SCA against EV71 observed under an inverted microscope. (A) Vero cells, (B) EV71-infected Vero cells. (C) Vero cells were exposed to various concentrations of SCA for $2 \mathrm{~h}$ and then infected with EV71 $\left(100 \times T_{C I D}\right)$ for $2 \mathrm{~h}$ (magnification, $\mathrm{x} 40$ ). (D) Vero cells exposed to various concentrations of SCA for $2 \mathrm{~h}$, then were infected with $\mathrm{EV} 71\left(100 \mathrm{xTCID} \mathrm{D}_{50}\right)$ for $2 \mathrm{~h}$. SCA was serially diluted to different concentrations $(0,31.25,62.5,125,500$ and $1,000 \mu \mathrm{g} / \mathrm{ml})$ in triplicate. $\mathrm{P}<0.05^{* * *} \mathrm{P}<0.01$ and ${ }^{* * * *} \mathrm{P}<0.001$ compared to the control; (E-G) Effective concentrations of SCA against EV71 observed under an inverted microscope. (E) Vero cells, (F) EV71-infected Vero cells, (G) EV71 was exposed to various concentrations of SCA prior to viral adsorption (magnification, $\mathrm{x} 40$ ). (H) EV71 exposed to various concentrations of SCA before viral adsorption. SCA was serially diluted to different concentrations $(0,31.25,62.5,125,500$ and $1,000 \mu \mathrm{g} / \mathrm{ml})$ in triplicate. ${ }^{* * * *} \mathrm{P}<0.001$ compared to the control; (I-K) Effective concentrations of SCA against EV71 observed under an inverted microscope. (I) Vero cells, (J) EV71-infected Vero cells and (K) Vero cells were infected with EV71 $\left(100 x \mathrm{TCID}_{50}\right)$ at $37^{\circ} \mathrm{C}$ under $5 \% \mathrm{CO}_{2}$ for $2 \mathrm{~h}$ and then supplemented with $\mathrm{SCA}(1,000 \mu \mathrm{g} / \mathrm{ml})($ magnification, $\mathrm{x} 40)$. (L) Vero cells were exposed to the virus $\left(100 \times \mathrm{xCID}_{50}\right)$ for $2 \mathrm{~h}$ and then supplemented with SCA. SCA was serially diluted to different concentrations $(0,31.25,62.5,125,500$ and $1,000 \mu \mathrm{g} / \mathrm{ml}$ ) in triplicate. ${ }^{*} \mathrm{P}<0.05$ compared to the control. SCA, sophocarpine; EV71, enterovirus 71

EV71 (100withe ${ }_{50}$ ) for $3 \mathrm{~h}$ at $4^{\circ} \mathrm{C}$ to allow for EV71 attachment to the cell surface. Subsequently, SCA was applied in concentrations of $1,000,500,250,125,62.5$, and $31.25 \mu \mathrm{g} / \mathrm{ml}$, and then the cells were incubated at $37^{\circ} \mathrm{C}$ to maximize the penetration of EV71. At 10-min intervals, the infected Vero cells were treated with PBS at $\mathrm{pH} 11$ for 1 min to inactivate the viruses that had not penetrated the cells. Then, PBS at pH 3 was immediately added to neutralize the PBS at pH 11. 

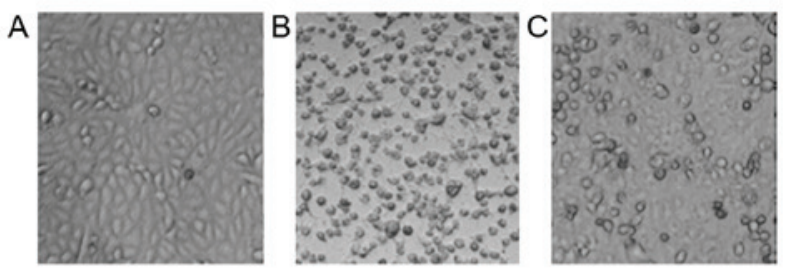

D

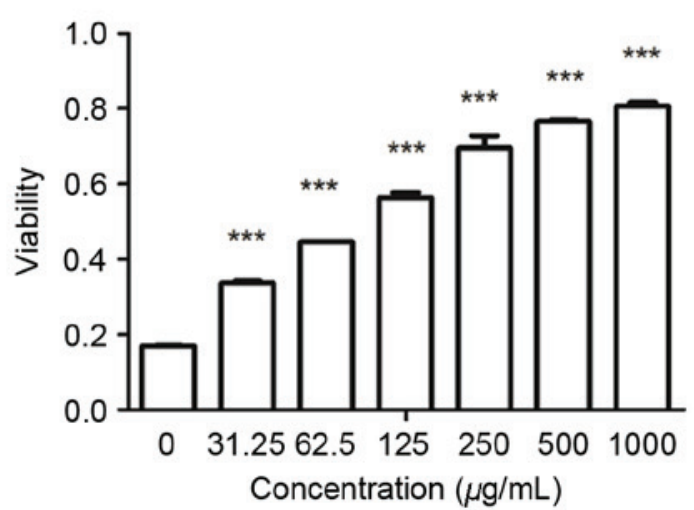

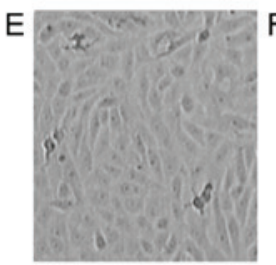
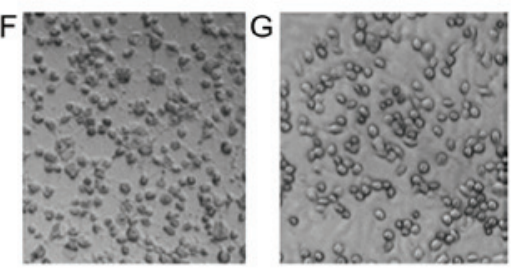

$\mathrm{H}$

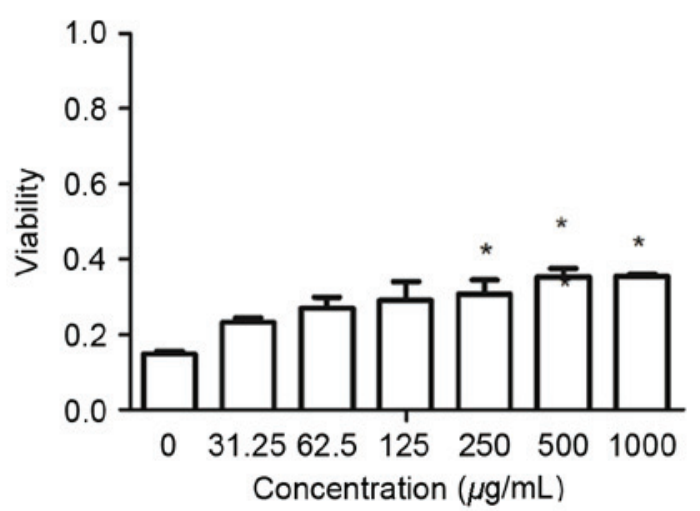

Figure 4. Effects of SCA on EV71 attachment and penetration. Images (A-C) of SCA on EV71 attachment observed under an inverted microscope. (A) Vero cells. (B) EV71-infected Vero cells. (C) Effects of SCA $(1,000 \mu \mathrm{g} / \mathrm{ml})$ on EV71 attachment (magnification, x40). (D) Vero cells were infected with EV71 $\left(100 \times\right.$ TCID $\left._{50}\right)$ under SCA concentrations of $0,31.25,62.5,125,500$ and $1,000 \mu \mathrm{g} / \mathrm{ml}$, and EV71 (100xTCID 50 absorption occurred for $2 \mathrm{~h}$ at $4{ }^{\circ} \mathrm{C}$. Images (E-G) of SCA on EV71 penetration observed under an inverted microscope. (E) Vero cells, (F) EV71-infected Vero cells. (G) Effects of SCA (1,000 $\mu \mathrm{g} / \mathrm{ml})$ on EV71 penetration (magnification, $\mathrm{x} 40)$. (H) Vero cells were infected with EV71 (100xTCID ${ }_{50}$ ) for $3 \mathrm{~h}$ at $4{ }^{\circ} \mathrm{C}$ to allow for EV71 attachment to the cell surface. Then, varying concentrations of SCA $(1,000,500,250,125,62.5$, and $31.25 \mu \mathrm{g} / \mathrm{ml})$ were added. ${ }^{*} \mathrm{P}<0.05$ and ${ }^{* * * *} \mathrm{P}<0.001 \mathrm{compared}$ to the control. SCA, sophocarpine; EV71, enterovirus 71.

The same procedure was repeated three times. The cytopathic effect was determined by measuring the cell viability via the MTT assay after $48 \mathrm{~h}(19)$.

Detection of viralRNA by RT-PCR. The Vero cells (4vir ${ }^{5}$ cells $/ \mathrm{ml}$ ) were seeded into a 24 -well culture plate (500 $\mu \mathrm{l} /$ well) and incubated for $24 \mathrm{~h}$ at $37^{\circ} \mathrm{C}$. The cells were exposed to EV71 $\left(100 x\right.$ TCID $\left._{50}\right)$ and varying concentrations of SCA and then incubated for $48 \mathrm{~h}$ at $37^{\circ} \mathrm{C}$. Subsequently, total RNA was extracted using TRIzol (Takara Bio, Inc.), and cDNA was synthesized from total RNA using reverse transcriptase with random primers and an oligo-dT primer. RT-PCR was performed in a $20 \mu \mathrm{l}$ reaction mixture containing $2.0 \mu \mathrm{l}$ of 10xPCR buffer, $1.6 \mu \mathrm{l}$ of dNTPs (10 mM each), $1.2 \mu \mathrm{l}$ of $\mathrm{Mg}^{2+}(25 \mathrm{mM}), 0.5 \mu \mathrm{l}$ of primer F, $0.5 \mu \mathrm{l}$ of primer R, $0.1 \mu \mathrm{l}$ of TaqDNA Polymerase,

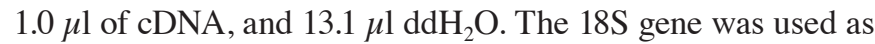
a reference gene (Table I). A PCR machine (GeneAmp 9700; Applied Biosystems Life Technologies, Foster City, CA, USA) is used to perform the thermal cycle of PCR amplification. The cycling conditions were as follows: $3 \mathrm{~min}$ at $95^{\circ} \mathrm{C}$; followed by 30 cycles of $95^{\circ} \mathrm{C}$ for $20 \mathrm{sec}, 45^{\circ} \mathrm{C}$ for $25 \mathrm{sec}$ and $72^{\circ} \mathrm{C}$ for $30 \mathrm{sec}$; and a final extension cycle at $72^{\circ} \mathrm{C}$ for $10 \mathrm{~min}$.

Statistical analysis. All data analysis was performed using the Statistical Package for Social Sciences software (version 19.0; SPSS Inc., IL, USA).

\section{Results}

Cytotoxicity assay of SCA. SCA induced slight cytotoxicity $(0-5 \%)$ against the host cells at concentrations of less than

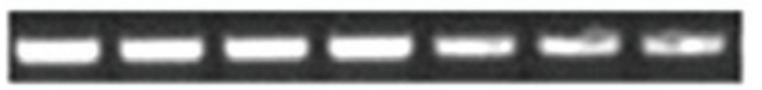
EV71

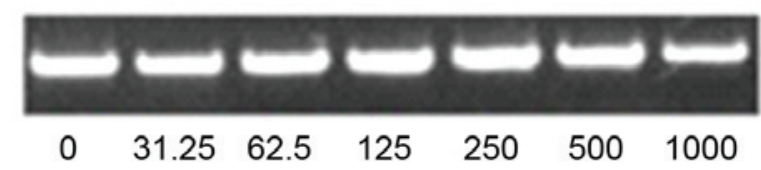

$18 \mathrm{~S}$

Figure 5. RT-PCR products of EV71 on 1\% agarose gel. The Vero cells were exposed to EV71 (100xTCID ${ }_{50}$ ) and varying concentrations of SCA and then incubated for $48 \mathrm{~h}$ at $37^{\circ} \mathrm{C}$. The SCA concentrations were 1,000, 500, 250, $125,62.5$, and $31.25 \mu \mathrm{g} / \mathrm{ml}$, respectively.

$125 \mu \mathrm{g} / \mathrm{ml}$, and it induced mild cytotoxicity (6-20\%) at concentrations between 250 and $1,000 \mu \mathrm{g} / \mathrm{ml}$ and induced over $50 \%$ cytotoxicity at concentrations more than $2,000 \mu \mathrm{g} / \mathrm{ml}$ (Fig. 1). The MTT assay showed that the $\mathrm{CC}_{50}$ of SCA was $1,346 \mu \mathrm{g} / \mathrm{ml}$.

$I C_{50}$ Determination by neutralization assay and selectivity index (SI). Cytotoxicity of SCA was determined using the MTT assay (Fig. 2). SCA was effective (P<0.001; Fig. 2D) against EV71 at a concentration of $250 \mu \mathrm{g} / \mathrm{ml}$. The morphological features of the Vero cells supplemented with a concentration of $500 \mu \mathrm{g} / \mathrm{ml}$ of SCA were observed under an inverted microscope (Fig. 2A-C). SCA showed high anti-EV71 activity at high concentrations, and the $\mathrm{IC}_{50}$ value of SCA was $350 \mu \mathrm{g} / \mathrm{ml}$. The selective index $\left(\mathrm{SI}=\mathrm{CC}_{50} / \mathrm{IC}_{50}\right)$ value for the MTT assay was 3.85 .

Antiviral assays. The Vero cells were exposed to various concentrations of SCA for $2 \mathrm{~h}$ and then infected with EV71 
$\left(100 \times\right.$ TCID $\left._{50}\right)$ for $2 \mathrm{~h}$ (Fig. 3A-D). This experiment indicated that SCA was highly effective against EV71 when it was used to pretreat the Vero cells for $2 \mathrm{~h}$.

When the Vero cells were infected with EV71 $\left(100 \times \mathrm{xCID}_{50}\right)$ that had been treated with SCA for $2 \mathrm{~h}$ (Fig. 3E-H). Fig. 3H shows a slight inhibitory activity at the $31.25 \mu \mathrm{g} / \mathrm{ml}$ and up to $1,000 \mu \mathrm{g} / \mathrm{ml}$.

The Vero cells were infected with EV71 (100 cell $\left.{ }_{50}\right)$ at $37^{\circ} \mathrm{C}$ under $5 \% \mathrm{CO}_{2}$ for $2 \mathrm{~h}$ and then supplemented with various concentrations of SCA (Fig. 3I-L). Our experiment demonstrated that SCA was statistically significant against EV71 only at concentrations up to the $500 \mu \mathrm{g} / \mathrm{ml}$ when it was applied after viral adsorption (Fig. 3L).

Effects of SCA on EV71 attachment and penetration. SCA was effective at inhibiting viral infection when it was added prior to viral infection. We hypothesized that SCA may inhibit viral attachment and/or penetration, thereby preventing viral entrance into cells. We found that SCA could significantly inhibit viral attachment at a concentration of $125 \mu \mathrm{g} / \mathrm{ml}$ $(\mathrm{P}<0.05 ;$ Fig. 4D). The morphological features of the Vero cells were observed under an inverted microscope (Fig. 4A-C).

Our experiment demonstrated that SCA induced only slight inhibitory effects on EV71 penetration (Fig. 4E-H).

Detection of viral RNA by RT-PCR. The cells were exposed to EV71 (100 ntrat $_{50}$ ) and varying concentrations of SCA and then incubated for $48 \mathrm{~h}$ at $37^{\circ} \mathrm{C}$. EV71 RNA was detected by RT-PCR (Fig. 5), and the 18S gene was used as the reference gene. Fig. 5 shows that the EV71 RNA levels continued to decrease when the concentrations of SCA increased.

\section{Discussion}

Because of the high incidence and high fatality rates of EV71 in children under six years of age, the development of an effective agent of treatment is urgently required. In China, traditional Chinese medicine was commonly used for treating infectious diseases. Many bioactive compounds exhibited antiviral activity in vitro and in vivo against human Enterovirus 71, including chebulagic acid (20), GuiQi polysaccharides (21), trans-retinoic acid (22), gallic acid and gramine derivatives $(23,24)$. Increasing evidences have suggested that SCA possible target substance, which can display anti-inflammatory effect in the mammary gland of mice and attenuate liver fibrosis in rats by inhibiting the TLR4 signaling pathway, and contribute to the protection of human immunological liver injury by regulating natural killer (NK) cell activity (25-27). Yang et al previously reported clemastanin B from Isatis indigotica root that showed useful antiviral activities in the therapy and prevention of human and avian influenza A and B viral infection in vitro (28). In this study, we demonstrated that SCA acts as potential drug against EV71 and that SCA is one of the many bioactive compounds of plant origin.

The results of this study indicated that SCA was highly effective against the cytopathicity of EV71 in vitro. The research results showed that the $50 \%$ cytotoxicity concentration of SCA used singly for Vero cells was $1,346 \mu \mathrm{g} / \mathrm{ml}$ and the 50\% inhibition concentration of SCA against EV71 was $350 \mu \mathrm{g} / \mathrm{ml}$. These findings indicate that SCA did not directly inhibit the cytotoxic effects of EV71 on the cells. The addition of SCA to the Vero cells before viral adsorption significantly suppressed EV71 infection, whereas the inhibitory effect was less significant when SCA was added after viral adsorption and used as a pretreatment on EV71 before viral adsorption. Thus, we supposed that SCA may inhibit viral attachment and/or penetration to prevent the entrance of the virus into the cells. The result suggests that SCA likely targets the EV71 virus by blocking the virus-cell attachment, and the inhibitory effect is likely derived from the binding of SCA molecules to the protein coat of the virus and/or to the host cell membrane.

The present findings suggest that SCA may be an early potential antiviral substance and that as a pretreatment may inhibit viral attachment, but additional investigation may serve to explore the molecular mechanism and provide further clarity.

\section{Acknowledgements}

The present study was supported by the provincial Key Research and Development program of Hebei, 17275505D.

\section{References}

1. McMinn PC: An overview of the evolution of enterovirus 71 and its clinical and public health significance. FEMS Microbiol Rev 26: 91-107, 2002.

2. Schmidt NJ, Lennette EH and Ho HH: An apparently new enterovirus isolated from patients with disease of the central nervous system. J Infect Dis 129: 304-309, 1974

3. Chen LC, Shyu HW, Chen SH, Lei HY, Yu CK and Yeh TM: Enterovirus 71 infection induces Fas ligand expression and apoptosis of Jurkat cells. J Med Virol 78: 780-786, 2006.

4. Chen TC, Lai YK, Yu CK and Juang JL: Enterovirus 71 triggering of neuronal apoptosis through activation of Abl-Cdk5 signalling. Cell Microbiol 9: 2676-2688, 2007.

5. Liang CC, Sun MJ, Lei HY, Chen SH, Yu CK, Liu CC, Wang JR and Yeh TM: Human endothelial cell activation and apoptosis induced by enterovirus 71 infection. J Med Virol 74: 597-603, 2004.

6. Liu J, Zhu M, Shi R and Yang M: Radix Sophorae flavescentis for chronic hepatitis B: A systematic review of randomized trials. Am J Chin Med 31: 337-354, 2003.

7. Yan JJ, Su IJ, Chen PF, Liu CC, Yu CK and Wang JR: Complete genome analysis of enterovirus 71 isolated from an outbreak in Taiwan and rapid identification of enterovirus 71 and coxsackievirus A16 by RT-PCR. J Med Virol 65: 331-339, 2001.

8. Wang SM, Liu CC, Tseng HW, Wang JR, Huang CC, Chen YJ, Yang YJ, Lin SJ and Yeh TF: Clinical spectrum of enterovirus 71 infection in children in southern Taiwan, with an emphasis on neurological complications. Clin Infect Dis 29: 184-190, 1999.

9. Jia CS, Liu JN, Li WB, Ma CM, Lin SZ, Hao Y, Gao XZ, Liu XL, Xu YF, Zhang LF and Qin C: The cross-reactivity of the enterovirus 71 to human brain tissue and identification of the cross-reactivity related fragments. Virol J 7: 47, 2010.

10. Du X, Wang H, Xu F, Huang Y, Liu Z and Liu T: Enterovirus 71 induces apoptosis of SH-SY5Y human neuroblastoma cells through stimulation of endogenous microRNA let-7b expression. Mol Med Rep 12: 953-959, 2015.

11. Cao L, Mao F, Pang Z, Yi Y, Qiu F, Tian R, Meng Q, Jia Z and Bi S: Protective effect of enterovirus-71 (EV71) virus-like particle vaccine against lethal EV71 infection in a neonatal mouse model. Mol Med Rep 12: 2473-2480, 2015.

12. Yue Y, Li P, Song N, Li B, Li Z, Guo Y, Zhang W, Wei MQ, Gai Z, Meng H, et al: Genomic and immunologic factors associated with viral pathogenesis in a lethal EV71 infected neonatal mouse model. Mol Med Rep 13: 4183-4190, 2016. 
13. Zhu FC, Liang ZL, Li XL, Ge HM, Meng FY, Mao QY, Zhang YT, $\mathrm{Hu}$ YM, Zhang ZY, Li JX, et al: Immunogenicity and safety of an enterovirus 71 vaccine in healthy Chinese children and infants: A randomised, double-blind, placebo-controlled phase 2 clinical trial. Lancet 381: 1037-1045, 2013.

14. Zhao XL, Gu DF, Qi ZP, Chen MH, Wei T, Li BX and Yang BF: Comparative effects of sophocarpine and sophoridine on hERG $\mathrm{K}^{+}$channel. Eur J Pharmacol 607: 15-22, 2009.

15. Wang XJ, Deng HZ, Jiang B and Yao H: The natural plant product sophocarpine ameliorates dextran sodium sulfate-induced colitis in mice by regulating cytokine balance. Int J Colorectal Dis 27: $575-581,2012$.

16. Yamada K, Ogawa H, Hara A, Yoshida Y, Yonezawa Y, Karibe K, Nghia VB, Yoshimura H, Yamamoto Y, Yamada M, et al: Mechanism of the antiviral effect of hydroxytyrosol on influenza virus appears to involve morphological change of the virus. Antiviral Res 83: 35-44, 2009.

17. Cheng HY, Lin CC and Lin TC: Antiherpes simplex virus type 2 activity of casuarinin from the bark of Terminalia arjuna Linn. Antiviral Res 55: 447-455, 2002.

18. De Logu A, Loy G, Pellerano ML, Bonsignore L and Schivo ML: Inactivation of HSV-1 and HSV-2 and prevention of cell-to-cel virus spread by Santolina insularis essential oil. Antiviral Res 48: 177-185, 2000.

19. Albin R, Chase R, Risano C, Lieberman M, Ferrari E, Skelton A, Buontempo P, Cox S, DeMartino J, Wright-Minogue J, et al: SCH 43478 and analogs: In vitro activity and in vivo efficacy of novel agents for herpesvirus type 2. Antiviral Res 35: 139-146, 1997.

20. Yang Y, Xiu J, Liu J, Zhang L, Li X, Xu Y, Qin C and Zhang L: Chebulagic acid, a hydrolyzable tannin, exhibited antiviral activity in vitro and in vivo against human enterovirus 71 . Int $\mathrm{J}$ Mol Sci 14: 9618-9627, 2013
21. Pu X, Wang H, Li Y, Fan W and Yu S: Antiviral activity of GuiQi polysaccharides against enterovirus 71 in vitro. Virol Sin 28: 352-359, 2013.

22. Chen S, Yang Y, Xu J, Su L and Wang W: Effect of all-trans-retinoic acid on enterovirus 71 infection in vitro. Br J Nutr 111: 1586-1593, 2014

23. Choi HJ, Song JH, Park KS and Baek SH: In vitro anti-enterovirus 71 activity of gallic acid from Woodfordia fruticosa flowers. Lett Appl Microbiol 50: 438-440, 2010.

24. Wei Y, Shi L, Wang K, Liu M, Yang Q, Yang Z and Ke S: Discovery of gramine derivatives that inhibit the early stage of EV71 replication in vitro. Molecules 19: 8949-8964, 2014.

25. Wang D, Xu N, Zhang Z, Yang S, Qiu C, Li C, Deng G and Guo M: Sophocarpine displays anti-inflammatory effect via inhibiting TLR4 and TLR4 downstream pathways on LPS-induced mastitis in the mammary gland of mice. Int Immunopharmacol 35: 111-118, 2016.

26. Qian H, Shi J, Fan TT, Lv J, Chen SW, Song CY, Zheng ZW, Xie WF and Chen YX: Sophocarpine attenuates liver fibrosis by inhibiting the TLR4 signaling pathway in rats. World J Gastroenterol 20: 1822-1832, 2014.

27. Huang YQ, Li PY, Wang JB, Zhou HQ, Yang ZR, Yang RC, Bai ZF, Wang LF, Li JY, Liu HH, et al: Inhibition of Sophocarpine on Poly I: C/D-GalN-induced immunological liver injury in mice. Front Pharmacol 7: 256, 2016.

28. Yang Z, Wang Y, Zheng Z, Zhao S, Zhao J, Lin Q, Li C, Zhu Q and Zhong N: Antiviral activity of Isatis indigotica root-derived clemastanin B against human and avian influenza A and B viruses in vitro. Int J Mol Med 31: 867-873, 2013. 